JURNAL KETAHANAN NASIONAL

Vol. 25, No. 3, Desember 2019, Hal 373-392

DOI:http://dx.doi.org/ 10.22146/jkn.48822

ISSN:0853-9340(Print), ISSN:2527-9688(Online)

Online sejak 28 Desember 2015 di :http://jurnal.ugm.ac.id/JKN

VOLUME 25

No. 3, Desember 2019

Halaman 373-392

\title{
Kerjasama Pertahanan Indonesia-Korea Selatan: KetahananMaritim Dan Transfer Teknologi Dalam Pengadaan Kapal Selam DSME 209/1400
}

\author{
Faris Al-Fadhat \\ Fakultas Ilmu Sosial dan Ilmu Politik, Universitas Muhammadiyah Yogyakarta \\ Email: farisalfadh@umy.ac.id \\ Naufal Nur Aziz Effendi \\ Program Studi Hubungan Internasional, Universitas Muhammadiyah Yogyakarta \\ Email:naufal_nurazizeffendi@yahoo.com
}

\begin{abstract}
This study examined Indonesian defense cooperation with South Korea in producing DSME 209/1400 submarines and how its impact towards Indonesian broader defense and maritime policy. Indonesia was expected to had adequate defense equipment to covered its large geographical areas. Nevertheless, most of the national army's defense equipment were old, while the domestic defenseindustry had just initiated. In this context, strategic cooperation was essential especially with countries which had advanced defense industries and technology. One example was Indonesian cooperation in submarine development with South Korea.

This study used qualitative analytical methods by looking at the main driving factors, impacts, and complex challenges of Indonesian defense policy in the submarine sector.

The results of this study showed that the Indonesia-South Korea cooperation was part of the country's strategy to strengthened its submarines vision in 2024. In contrast to other existing cooperation which emphasizing on equipment trade, the agreement with South Korea had also initiated the process of technology transfer to helped Indonesian maritime defense for longer term. However, the findings of this study showed that the cooperation had serious challenges, especially with regards to human resources and budget allocation.
\end{abstract}

\section{Keywords: Indonesia-South Korea, Defense Cooperation, Submarine, Technology Transfer.}

\begin{abstract}
ABSTRAK
Penelitian ini bertujuan untuk mengkaji kebijakan kerjasama pertahanan Indonesia dengan Korea Selatan dalam hal pengadaan Kapal Selam DSME 209/1400 dan dampak yang ditimbulkan terhadap politik pertahanan dan maritim Indonesia. Sebagai negara yang menganut politik pertahanan defensif, Indonesiadituntutuntuk memiliki strategi alutsistayang sesuai dengan kondisi geografisnya. Sementara itu, pengembangan industri pertahanan nasional baru saja dimulai di tengah kondisi usia alutsista TNI yang sebagian besar sudah tua. Oleh karena itu, kerjasama dengan negara-negara yang memiliki industri pertahanan maju merupakan sebuah kebijakan strategis. Salah satunya adalahkerjasama Indonesia dengan Korea Selatan di bidang pengembangan kapal selam.

Penelitian ini menggunakan metode kualitatif analitis dengan melihat faktor-faktor pendorong utama, dampak, serta tantangan yang cukup kompleks dari kebijakan pertahanan Indonesia di sektor kapal selam.

Hasil dari penelitian ini menunjukkan bahwa kebijakan kerjasama Indonesia-Korea Selatan pada dasarnya merupakan upaya untuk memperkuat visi pengadaan kapal selam Indonesia pada tahun 2024. Berbeda dari beberapa kerjasama serupa yang bersifat pembelian alat pertahanan semata, kesepakatan yang ditandatangani tahun 2011 ini turut mengikusertakan proses transfer teknologi untuk menjamin keberlanjutan kemandirian maritim Indonesia.
\end{abstract}


Meski demikian, temuan dalam penelitian ini menunjukkan bahwa kerjasama bilateral tersebut memiliki hambatan yang perlu diselesaikan, khususnya di sektor kesiapan SDM Indonesia serta anggaran yang masih terbatas.

Kata Kunci: Indonesia-Korea Selatan Kerjasama Pertahanan, Kapal Selam, Transfer Teknologi.

\section{PENGANTAR}

Sebagai negara kepulauan yang memiliki luas daratan mencapai $1.922 .570 \mathrm{~km}$ persegi dan luas perairan sebesar $3.257 .483 \mathrm{~km}$ persegi, Indonesia dituntut untuk memiliki pertahanan yang mampu menjaga kedaulatan. Salah satu stategi pertahanan yang perlu mendapat perhatian adalah menyangkut alat utama sistem senjata (alutsista). Alutsista menjadi perhatian yang cukup serius di mata pemerintah mengingat alutsista Tentara Nasional Indonesia (TNI) masih dibawah standar penangkalanatau sebagian besar usianya sudah sangat tua karena diproduksi sejak akhir tahun 1950-an(Romansyah, 2015). Selain itu, dalam memenuhi kebutuhan perawatan dan kebutuhan suku cadang alutsista, Indonesia masih sangat bergantung pada negara lain. Dalam periode tahun 20002011, faktanya kondisi alutsista Indonesia jauh tertinggal dari negara lain. Di antara negaranegara ASEAN, Indonesia berada di posisi paling bawah (Schreer, 2013).

Undang-Undang No. 16 Tahun 2012 tentang Industri Pertahanan merupakan usaha pemerintah melalui industri dalam negeri di tahun 2012 untuk mengembangkan alutsista Indonesia dikarenakan kondisi alutsista yang melemah. Secara detail, hal tersebut disebutkan dalam Pasal3dan4yangmengaturmengenai fungsi dan tujuan penyelenggaraan industri pertahanan(Romansyah, 2015: 2).Adapun tujuan pengembangan dan pemanfaatan industri pertahanan dan keamanan tertera di Pasal 3 yang berbunyi "mewujudkan kemandirian pemenuhan alat peralatan pertahanan dankeamanan; meningkatkan kemampuan memproduksi alat-peralatan pertahanan dan keamananyangakandigunakandalam rangkamembangun kekuatan pertahanan dan keamanan yang andal;dan memandirikan sistem pertahanan dan keamanan”.

Namun demikian, pembangunan industri pertahanan dalam negeri tersebut pada perjalanannya ternyata memunculkan masalah tersendiri,antara lain pengembangan industri pertahanan nasional. Negara dituntut untuk sesegera mungkin memenuhi kebutuhan sektor pertahanan. Pengadaan alutsista pada dasarnya tidak dapat menunggu waktu yang lama sebab alutsista merupakan bagian integral dari Renstra dan sasarannya alutsista itu harus siap digunakan kapanpun sesuai kebutuhan.

Pasal 43 Undang-Undang No.16 Tahun 2012 tentang Industri Pertahanan menyatakan bahwa prioritas pengadaan alat utama sistem senjata harus berasal dari industri dalam negeri, namun jika industri dalam negeri belum dapat memenuhi kebutuhan tersebut, maka pengadaan dari luar negeri dimungkinkan sepanjang memenuhi beberapa persyaratan. Persyaratan terpenting dimaksud adalah offset pertahanan dalam bentuk alih teknologi, imbal dagang, kandungan lokal, dan offset minimal $85 \%$ yang diperhitungkan dari nilai pengadaan alutsista.

Sebagai negara yang tengah melakukan pengembangan industri pertahanan dalam negeri, Indonesia perlu melakukan banyak kerjasama dalam pertahanan dengan negaranegara yang memiliki industri pertahanan 
yang telah maju.Salah satu bentuk kerjasama pertahanan adalah kerjasama bilateral dengan Korea Selatan khususnya dalam pengembangan kapal selam.Kerjasama tersebut dilakukan dengan latar belakang keinginan Indonesia untuk memenuhi target pada tahun 2024 untuk memiliki 12 unit kapal selam.Penandatangan kontrak oleh pemerintah Indonesia dengan Korea Selatan senilai US\$ 1.1 miliar untuk pembelian 3 unit kapal selam series DSME-209 telah dilaksanakan pada tahun 2011. Dilengkapi dengan Improved Changbogo, Kapal selam DSME-209adalah salah satu varian kapal selam U-209 yang dilisensi oleh Korea Selatan dari Jerman. Dalam kontrak pembelian tersebut disebutkan bahwa 1 dari 3 unitterakhir kapal selam yang dibeli Indonesia diproduksioleh Galangan Kapal Nasional, PT. PAL Surabaya. Apabila ditinjau dari segi fisik, Kapal DSME209/1400 tersebut pada dasarnya adalah penyempurnaan serta perkawinan desain antara kapal jenis 209/1300 Cakra milik Indonesia dengan kapal selam jenis 209/1200 Changbogo milik Korea Selatan(Jalo, 2015).

Berdasarkan uraian di atas, tulisan ini bermaksud untuk menjelaskan bentuk kebijakan kerjasama pertahanan Indonesia dengan Korea Selatan sertadampaknya terhadap visi pertahanan nasional Indonesia. Selain itu, tulisan ini juga dimaksudkan untuk menelaah kompleksitas dan hambatan yang dihadapi Indonesia dalam kerjasama tersebut. Dengan menggunakan metode kualitatif analitis, dimana data-data dikumpulkan melalui library research melalui pemanfaatan data sekunder yang diolah dari buku, artikel, jurnal,dan berita, peneliti berargumen bahwa kebijakan kerjasama Indonesia-Korea Selatan merupakan upaya untuk memperkuat visi pengadaan kapal selam Indonesia pada tahun
2024. Berbeda dari beberapa kerjasama serupa yang bersifat pembelian alat pertahanan semata, kesepakatan yang ditandatangani tahun 2011 ini juga turut mengikusertakan proses transfer teknologi untuk menjamin keberlanjutan kemandirian maritim Indonesia. Meski demikian, penelitian ini juga menemukan bahwa kerjasama ini memiliki hambatan yang perlu diselesaikan khususnya di sektor kesiapan SDM Indonesia serta anggaran yang masih terbatas.

\section{PEMBAHASAN}

\section{Postur Pertahanan Indonesia}

Pada dokumen Kebijakan Pertahanan Negara tentang Minimum Essential Forces(MEF)dinyatakan bahwa Kementerian Pertahanan bertugas untuk menyiapkan postur pertahanan negara yang disusun berdasarkan keterpaduan antara kekuatan, kemampuan, dan penggelaran sumber daya nasional yang disusun dalam sistem pertahanan negara (Badan Sarana Kementrian Pertahanan Republik Indonesia, 2010).Dalam hal ini, postur pertahanan negara dikembangkan dari strategi pertahanan negara dengan menimbang faktor geopolitik dan geostrategi Indonesia, serta karakteristik Negara Kesatuan Republik Indonesia yang merupakan kepulauan yang memiliki wilayah perairan yang luas. Postur pertahanan militer dikembangkan pada pola Tri-Matra Terpadu antara kekuatan matra darat, kekuatan matra laut, dan kekuatan matra udara(Sisriadi, 2016).

Selain itu, dijelaskan bahwa kekuatan pertahanan militer juga mencakup beberapa aspek diantaranya organisasi, peralatan utama sistem senjata dan pendukungnya, serta aspek pangkalan. Terdapat lima kemampuan utama yang dimiliki oleh pertahanan militer yang di antaranya adalah kemampuan pertahanan, 
kemampuan intelijen, kemampuan dukungan, kemampuan pemberdayaan wilayah, dan kemampuan keamanan. Dalam hal ini, kekuatan pertahanan yang sudah terbentuk secara profesional kemudian dikembangkan pada suatu gelar kekuatan pertahanan militer yang digunakan untuk mengimplementasikan strategi pertahanan negara untuk menghadapi ancaman nyata dan menangkal ancaman potensial (Puspen TNI, 2007).

Dalam rangka mewujudkan postur pertahanan yang ideal setidaknya terdapat tiga parameter yang dapat digunakan, yaitu strategi pertahanan negara, postur pertahanan militer, dan doktrin TNI.Strategi pertahanan negara yang berlaku saat ini pada faktanya lebih menitikberatkan pada pertimbangan ancaman, sehingga secara substantif bersifat prosedural. Sedangkan pertimbangan konstelasi geografis kurang mendapat porsi yang memadai. Postur pertahanan militer di Indonesia sebagian besar lebih mengakomodasi aspek taktis yang mencakup konsep kemampuan, kekuatan, dan gelar kekuatan. Dalam hal ini, faktor geografismasih belum terefleksikan secara jelas dalam postur pertahanan militer. Setidaknya, hal tersebut dapat dilihat dari gelar kekuatan yang belum proporsional ditinjau dari aspek kematraan. Akhirnya, Doktrin TNI, yaitu Tri Dharma Eka Karma,sebagaimana tampak dalam konsep Tri-matra Terpadu, lebih memberikan gambarantentang penggabungan antarasatuan-satuan ketiga matra dalam satukomando tugas gabungan dimana komposisinya disesuaikan dengan karakteristik ancaman dan jenis operasi yang akan dilaksanakan (Puspen TNI, 2007).

Secara umum, pembuatan pertahanan militer dapat digambarkan sebagai kolaborasi dinamis antara fungsi-fungsi peperangan yang ada pada masing-masing matra yang dipadukan, sehingga menghasilkan satu kekuatan pertahanan militer yang solid untuk menghadapi ancaman. Adapun yang dimaksud dengan fungsi peperangan adalahpengelompokan kegiatan dan sistem yang memiliki kesamaanyang digunakan oleh Panglima untuk melaksanakan berbagai upaya untuk mencapai tujuan peperangan. Sisriadi (2016) menyebutkan bahwa fungsi-fungsi tersebut mencakup6 fungsi, yaitu fungsisensor, fungsi komandodan pengendalian,fungsi pemukul,fungsi mobilitas,fungsi proyeksi kekuatan, danfungsi dukungan (Sisriadi, 2016). Adapun fungsi-fungsi tersebut akan dijelaskan sebagai berikut.

Pertama, fungsi sensor. Fungsi sensor dijelaskan sebagai kegiatan pengumpulan dan pengolahan informasi atau data menjadi intelijen, dan juga distribusi intelijenterhadap hal-hallainyangadadalam mandala operasi. Fungsi sensor pertahanan militer sendiri disusun secara bertahap, dimulai dengan tingkat taktis, operasional sampai dengan tingkat strategis. Fungsi sensor dianggap cakap apabila dapat memadukan sensor teknis seperti radar dan satelit dengan sensor manusia secaraproporsional. Penyelenggaraan fungsi sensor dapat optimal apabila didukung oleh sistemsensor yang handaldengan mengkolaborasikan kepiawaian sistem penginderaan jarak jauh yang didukung oleh komputer dengan teknologi informatika serta sistem komunikasi yang terpecaya dan aman (Puspen TNI, 2005).

Kedua, fungsi komando dan pengendalian. Dalam hal ini,fungsi komando dan pengendalian diartikan sebagai kegiatan penggunaan kekuasaan dan kewenangan oleh seorang komandandalam melaksanakan tugas atau operasi secara tepat terhadap 
satuan di bawahnya atausatuan-satuan lain yang berada dibawah kewenangannya. Dari definisi tersebut, dapat diartikan bahwa komando dan pengendalian merupakan pusat dari kegiatan peperangan yang dilakukan dalam kampanye militer di dalam mandala perang baik secara lansun maupun tidak langsung. Fungsi tersebut sangat penting dalam menentukan keberhasilan peperangan. Pada pelaksanaannya, fungsi komando dan pengendalian dilakukan oleh Panglima atau Komandan yang didukung oleh sistem komando dan kendali yang meliputi fasilitas dan peralatan, personel, prosedur, dan manajemen informasi (Puspen TNI, 2005)

Ketiga, fungsi pemukul. Fungsi pemukul diselenggarakan dengan menggunakan peralatan utama sistem senjata atau alutsista untuk menghancurkan kekuatan lawan. Alutsista adalah salah satu elemen utama dari fondasi pertahanan militer yang menghasilkan efek penggentar (deterrence effect) untuk mencegah lawan melakukan penyerangan terhadap negara lain. Oleh karena itu, pengembangan kekuatan pertahanan militer harus memberikan perhatian lebih pada pengadaan alutsista, baik buatan dalam negeri maupun luar negeri (Pramodhawardani, 2009).

Pengadaan alutsista dalam rangka pengembangan kekuatan pertahanan militer suatu negara seringkali terkendala oleh beberapa masalah. Di negara berkembang,masalah klasik yang mengemuka adalah keterbatasan jumlah anggaran pemerintah, sedangkan pada negara-negara maju masalahnya adalah rendahnya dukungan masyarakat terhadap penggunaan anggaran pemerintah untuk belanja militer. Oleh karena itu, setiap negara selalu berupaya untuk meningkatkan efisiensi dalam proses akuisisi alutsista (Pramodhawardani, 2009).

Belajar dari pengalaman negara lain, salah satu upaya untuk meningkatkan efisiensi akuisisi alutsista adalah dengan membuat perencanaan kebutuhan alutsista secara terintegrasi yang dapat diperoleh dari perencanaan secara terintegrasi. Perencanaan yang baik tersebut ditandai dengan meningkatnya interoperabilitas dan interkoneksivitas pada saat dioperasikan oleh masing-masing matra di daerah operasi (Pramodhawardani, 2009).

Selain upaya di atas, terdapat upaya lain yang dapat ditempuh yaitu dengan memproduksi alutsista secara mandiri. Terbitnya Undang-Undang No.16 Tahun 2012 sebagai salah satu upaya pemerintah dalam pemberdayaan industri pertahanan dalam negeri patut diapresiasi karena melalui penggunaan produk-produk industri pertahanan dalam negeri pemerintah dapatmemaksimalkan penggunaan anggaran pertahanan untuk pengadaan alutsista buatan luar negeri yangsangat penting namun tidak dapat diproduksi mandiri dalam negeri (Sisriadi, 2016).

Keempat, fungsi mobilitas. Fungsi mobilitas sendiri didefinisikan sebagai penyelenggaraan kegiatan pemindahan pasukan dari satu daerah operasi kedaerah operasi lain di mandala perang yang bertujuan untuk mendekatkan pasukan sendiri kepada musuh atau memusatkan kekuatan.Dalam fondasi pertahanan militer, fungsi mobilitas memiliki peran yang paling krusial apabila dihadapkan pada luas wilayah dan kondisi geografis di Indonesia yang merupakan negara kepulauan.Dalam hal ini, penyelenggaraan fungsi mobilitas harus didukungoleh sistem transportasi 
militer yang mampu memobilisasi pasukan secara tepat waktu dan tepat tujuan (Sisriadi, 2016).

Kelima, fungsi proyeksi kekuatan. Fungsi proyeksi kekuatan sendiri didefinisikan sebagai kegiatan penggunaankekuatan militer untuk mengatasi suatu krisis, meningkatkan stabilitas kawasan, dan memberikan efek tangkal.Istilah tersebut digunakan oleh banyak negara dengan pengertian yangberbeda-beda sesuai dengan karakteristik geografi negara yang bersangkutan (Sisriadi, 2016).

Keenam, fungsi dukungan. Dalam hal ini, fungsi dukungan merupakan fungsi yang berkaitan dengan kemampuan dukungan militer dalam penyelenggaraan pertahanan negara dan keamanan nasional serta pemberdayaan wilayah pertahanan. Fungsi dukungan sendiri memiliki spektrum yang sangat luas, baik dalam OMP maupun OMSP. Dalam OMP, fungsi dukungan mencakup dukungan operasi pertahanan udara nasional, dukungan operasi intelijen, dukungan operasi teritorial, dukungan operasi informasi, dukungan operasi NUBIKA, dukungan operasi PERNIKA, dukungan operasi SURTA, dukungan operasi khusus,dukungan operasi pengungsian, dan dukungan operasi SAR. Sedangkan pada OMSP, fungsi dukungan mencakup dukungan bantuan penganggulangan bencana dan keamanusiaan, dukungan operasi pengungsian dan dukungan operasi pemeliharaan perdamaian dunia (Sisriadi, 2016).

Selain pembentukan pertahanan milliter berlandaskan enamprinsip di atas, strategi dalam membangun postur pertahanan Indonesia yang ideal dapat juga mengacu pada MEF (Minimum Essential Forces).
Konsep MEF sendiri didefinisikan sebagai suatu standar kekuatan pokok minimum TNI yang disiapkan sebagai prasyarat utama serta merupakan dasar bagi efektivitas tugas pokok dan fungsi TNI dalam menghadapi ancaman yang bersifat aktual (Badan Sarana Kementrian Pertahanan Republik Indonesia, 2010).Minimum Essential Forcesmerupakangebrakan pemerintah dalam subjek kebijakan pertahanan nasional. MEF adalah amanat pembangunan nasional di bidang pertahanan keamanan yang ditetapkan dalam Rencana Pembangunan Jangka Menengah Nasional (RPJMN) Periode 2010-2014.Implementasi MEF dibagi ke dalam tiga rencana strategis atau renstra, yaituRenstra 1 tahun 2010-2014,Renstra 2 tahun 2015-2019, dan terakhir Renstra 3 tahun 2020-2024. Dalam Renstra 1, pemerintah menganggarkan dana sebesar 156 Trilliun untuk penyediaan alutsista (Saragih, 2013). Pada Selanjutnya, pada Renstra 2, pemerintah menganggarkan dana untuk TNI sebesar 106 Trilliiun (Supriatin, 2018), sedangkan untuk Renstra 3 masih direncanakan penganggarannya.

Untuk mengidealkan postur pertahanan dan disegani baik di kancan regional maupun internasional, MEF bertujuan untuk mencapai ketentuan pokok minimum tersebut. Tekanan pada kata minimum merajuk pada fakta bahwa MEF merupakan satu bentuk kekuatan pokok yang memenuhi standard tertentu serta memiliki efek tangkal sehingga tidak merajuk kepada konsep perlombaan senjata maupun sebagai strategi membangun kekuatan untuk memenangkan peran secara total (Rusman, 2018).

Adapun ekspektasi utama pengimplementasian MEF adalah untuk mendorong Indonesia memiliki sebuah 
kekuatan pertahanan yang handal yang mampu dioperasikan dan tidak bergantung pada asistensi negara lain. Oleh karena itu, MEF difokuskan pada pembangunan alutsista TNI dengan meninjau jenis dan produk alutsista yang dibutuhkan, anggaran pembelian alutsista, dan durasi pengadaan alutsista yang dibutuhkan.Dalam hal ini, Indonesia mempunyai industri dalam negeri melalui PT. PINDAD sebagai tempat produksi senjata, amunisi, dan kendaraan; PT. PAL yang menangani pembuatan kapal; dan PT. Dirgantara Indonesia untuk pesawat terbang (Rusman, 2018).

Berangkat dari kesadaran akan pentingnya peningkatan kualitas TNI, pemerintah Indonesia sudah merevitalisasi alutsista yang dimiliki TNI, khususnya yang usianya sudah tua. Hal ini mengingat luas laut dalam negeri yang dimiliki Indonesia seluas $93.000 \mathrm{~km}$ persegi (termasuk di dalamnya teluk, selatdan laut ditambah juga dengan area laut luar dan dan ZEE (Zona Eknonomi Eksklusif)mencapai total luas $5.000 .000 \mathrm{~km}$ persegi (Rusman, 2018).Dalam hal ini, salah satu alutsista yang perlu direvitalisasi TNI adalah kapal selam. Sejak Perang Dunia I, kapal selam sering digunakan sebagai pemburukapal permukaan yang mematikan dan diuntungkan karena kesenyapannya. Salah satu keunggulan kapal selam adalah mampu memberikan efek penggentar (deterrence effect) yang efektif untuk musuhnya (Rizanny, 2017).

Stealth, covert, dan asimetris merupakan strategi pertempuran dan teknologi yang dimiliki kapal selam yang memberikan keuntungan akses di laut secara tidak langsung dan memberikan banyak keuntungan yang bisa membuahkan kemenangan serta memberikan efek besar kepada musuh danlebih superior daripada kapal perang lainnya.Mengingat angkatan laut Indonesia juga mengoperasikan kapal selam, maka dari itu pemanfaatan atas kelebihan yang dimiliki kapal selam sangat penting(Rizanny, 2017).

Menentukan seberapa banyak kekuatan kapal selam yang diperlukan dan bagaimana pola operasi untuk kapal selam merupakan tugas berat bagi Indonesia.Indonesia memerlukan kapal selam konvensional yang berukuran besar agar dapat beroperasi jauh dari pangkalan untuk mencermati letak geografis dan perkembangan lingkungan strategis regional(Rizanny, 2017).

Di masa datang satuan kapal selam nantinyadiharapkan bisa berkontribusi dalam mendorong peran kepemimpinan Indonesia baik itu di tingkat Asia Tenggara serta ikut serta dalam memelihara perdamaian dunia sesuai denganparadigma yang dimiliki TNI AL yakni menjadi angkatan laut berkelas dunia (World Class Navy) (Rizanny, 2017).

\section{Kerjasama Pertahanan Indonesia-Korea Selatan}

Kerjasama pertahanan Indonesia dan Korea Selatan pada pemenuhan alutsista angkatan laut dimulai pada saat penandatanganan Memorandum of Understanding pada Navy to Navy Talks antara TNI AL dengan Angkatan Laut Korea ditandatangani pada bulan Desember 2016. Selain itu, Korea Selatan juga meningkatkan kerjasama di bidang jual beli peralatan militer seperti yang tertuang dalam kontrak penjualan 8 unit CN-235 berdasarkan pada Letter Of Agreement yang ditandatangani oleh wakil dari kedua negara pada bulam April 1997 (Seung-Yoon, 2005).

Dalam laporan tahunan 1994-1995 disebutkan bahwa TNI-AL sedang memesan 1 
buah Ocean Going Tug Boat atau Kapal Tunda Samudra yang masih diproses di galangan kapal Daewoo Pusan. Korea Selatan juga pernah memproses kendaraan militer (jeep dan truk), tank ringan, plant amunisi, kapal perang, angkatan laut, amunisi, alat-alat anti demonstrasi, dan parasut terjun payung untuk diekspor ke Indonesia sesuai dengan jumlah yang telah disepakati (Dewan Perwakilan Rakyat Republik Indonesia, 2012).

Kerjasama pada bidang pertahanan yang pernah terjalin antara Indonesia dengan Korea Selatan diantaranya adalah perjanjian mengenai pengaturan pelaksanaan antara Departemen Pertahanan dan Keamanan Republik Indonesia dengan Kemitraan Pertahanan Republik Korea Selatan tentang penerimaan bersama jaminan mutu antar pemerintah untuk material dan jasa pertahanan(Agreement Between the Department of Defence and Security of the Republic of Indonesia and the Ministry of National Defence of the Republic of Korea Concerning Mutual Acceptance of Government Quality Assurance of Defence Materiel and Services) yang ditandatangani di Jakarta pada tanggal 7 Oktober 1999(Dewan Perwakilan Rakyat Republik Indonesia, 2012).

Selain penandatangan kontrak di atas, kontrak berupa Letter of Intent atau kerjasama khusus industri pertahanan antaraDepartment Pertahanan Republik Indonesia dengan Kementrian Pertahanan Nasional Republik Korea(Letter of Intent for Specific Defence Industry Cooperation between the Department of Defence of the Republic of Indonesia and the Ministry of National Defence of the Republic of Korea) juga ditandatanganitepatnya pada tanggal 22 Desember 2000 di Jakarta (Ministry of Foreign Affairs of The Republic of Indonesia).

Selanjutnya,pada tanggal 4 Desember 2006 hubungan bilateral Indonesia dan Korea
Selatan ditingkatkan menjadi kemitraan strategis melalui penandatanganan Joint Declaration on Strategic Partnershipoleh Presiden RI Soesilo Bambang Yudhoyono dan Presiden Korea Selatan Roh Moo Hyun di Jakarta. Joint Declaration on Strategic Partnership memiliki tiga pilar kerjasama, yakni kerjasama politik dan keamanan, kerjasama ekonomi, perdagangan dan investasi, dan kerjasama sosial budaya(KBRI Seoul, tt). Selain itu, pada tanggal 6-8 Maret 2009 Presiden ROK, Lee Myung-bak juga menyepakati sebuah LOI (Letter of Intent) di bidang pertahanan (Dewan Perwakilan Rakyat Republik Indonesia, 2012) yaitu berupa pengembangan kerjasama proyek jet perang antara Departemen Pertahanan Republik Indonesia dan Administrasi Program Akusisi Pertahanan Republik Korea (Letter of Intent on Co-development of a Fighter Jet Project between the Department of Defence of the Republic of Indonesia and the Defence Acquisition Program Administration of the Republic of Korea) (Ministry of Foreign Affairs of The Republic of Indonesia, 2014).

Tepatnya pada tanggal 15 Juli 2010 bertempat di Seoul, Pemerintah Indonesia menandatanganiMemorandum of Understanding (MOU) mengenai kerjasama pengembangan pesawat tempur KF-X yang kemudian dilanjutkan dengan kontrak tentang Technology Development Phase Programatau pengembangan Pesawat Tempur KF-X/IF-X pada tanggal 20 April 2011 di Daejeon. Berdasarkan peraturan Presiden tentang program pengembangan pesawat tempur IF$\mathrm{X}$, tahapan pengembangan pesawat tempur IF-X dibagi dalam tiga tahap, yaitutahap pengembangan teknologi,tahap pengembangan rekayasa serta manufaktur, dantahap produksi. Tahap pengembangan teknologi merupakan 
tahapan untuk membangun persyaratan operasional, identifikasi teknologi, dan desain konfigurasi Pesawat Tempur IF-X (Jalo, 2015).

Kerjasama antara Indonesia dengan Korea Selatan industri pertahanan dipusatkan pada pengembangan kapal selam kelas changbogo dan pengembangan pesawat temput KFX/ IFX. Kedua proyek ini menjadi fokus utama kerjasama strategis antara Indonesia dengan Korea Selatan. Kapal selam kelas changbogo sendiri memiliki beberapa teknologi mutakhir seperti Latest Combat System, Enchanced Operating System, Non-hull penetrating mast, and Comfortable Accommodation. Dalam hal ini, pembelian kapal selam changbogo memiliki tujuan untuk memenuhi kebutuhan TNI Angkatan Laut (Jalo, 2015).

\section{Pembelian dan Pengembangan Kapal Selam DSME 209/1400}

Sebagaimana diuraikan sebelumnya, kapal selam telah menjadi salah satu program prioritas modernisasi alutsista TNI Angkatan Laut. Disamping memiliki teknologi persenjataan yang tinggi, kapal selam juga mampu memberikan efek deterrence atau daya tangkalterhadap negara lain yang berupaya secara ilegal memasuki perairan nasional(Meidiani, 2018). Dengan alokasi anggaran pengadaan 3 unit kapal selam yang sangat besar yang kemudian dibagi dalam dua rencana strategis (Renstra) yaitu Renstra I tahun 2004-2009 sebesar 350 juta dolar Amerika Serikat, dan Renstra II tahun 20102014 sebesar 730 juta dolar AmerikaSerikat, Indonesia melaui industri dalam negeri berkeinginan untuk menguasai teknologi kapal selam(Inspektorat Jenderal Kementrian Pertahanan Republik Indonesia, 2014).

Selain memiliki daya tangkal yang baik, pentingnya Indonesia memiliki kapal selam juga memiliki tujuan untuk menjaga wilayah laut Indonesia yang memiliki luas 93.000 $\mathrm{km}$ persegi meliputi selat, teluk, dan laut ditambah dengan area laut luar termasuk laut teritorial dan Zona Eknonomi Eksklusif (ZEE) yang totalnya mencapai 5.000.000 $\mathrm{km}$ persegi (Rusman, 2018).Dalam hal ini, diharapkan satuan kapal selam tersebut dapat memberikan kontribusi yang signifikan terhadap negara Indonesia sebagai leadership role di kawasan regional dan ikut serta dalam permasalahan global (Agussalim \& Alfadh, 2011).Hal ini konsisten dengan paradigma TNI AL yaitu menjadi angkatan laut berkelas dunia (World Class Navy) (Rizanny, 2017).

Korea Selatan dipilih sebagai tempat pembelian kapal selam tak lain karena pertimbangan harga yang lebih murah dari negara lain. Untuk tiga kapal selam, Korea Selatan mematok hargasebesar USD 1 miliar, sedangkan harga dari negara lain per unit mencapai USD 450 juta-USD 500 juta. Menurut Rahmat Lubis, Kepala Badan Sarana Pertahanan Kementerian Pertahanan, pembelian tiga kapal selam dari Korsel adalah seharga USD 1 miliar. Dalam hal ini, dengan kisaran harga tersebut adalah tidak mungkin bagi pemerintah untuk dapat membeli kapal selam dari negara Eropa yang harganya berkisar USD 450-USD 500 juta hanya untuk satu kapal selam. Selain masalah harga, Korea Selatan dapat dikatakan sebagai mitra yang mumpuni dari segi kualitas, bahkan dalam pengadaan selalu cepat dalam pengiriman barang.

Rahman Lubis menambahkan,selama ini produsen kapal selam Korea Selatan berkenan datang ke Indonesia dan membimbing PT PAL Indonesia untuk memproduksi kapal selam sendiri. Kapal selam dari Korea Selatan juga memiliki kualitas dan kecanggihan yang sama 
dengan kapal selam sejenisnya. Memiliki berat 1.600ton, kapal selam produksi Korea Selatan juga dilengkapi dengan torpedo. Dalam hal ini, kecanggihan diesel elektrif kapal selam produksi Korea Selatan relatif sama dengan kapal selam yang lain yaitu harus senyap dalam kurun waktu yang lama, dan dilengkapi dengan persenjataan yang memenuhi standar (Julaikah, 2014).

Kapal selam changbogo dipilih oleh Kementerian Pertahanan karena dinilai memiliki teknologi yang membuat kapal selam ini menjadi sangat senyap namun mematikan. Pemilihan kapal selam changbogo di antaranya dipengaruhi oleh pertimbangan doktrin perang Indonesia yang menempatkan peperangan sebagai upaya untuk bertahan dan tidak memiliki niat untuk melakukan penyerbuan ataupre-emptive strike ke kawasan luar wilayah Indonesia. Walaupun kapal selam changbogo relatif kecil, dengan doktrin tersebut, kapal selam changbogo dianggap mumpuni untuk bermanuver di wilayah perairan Indonesia. Selain itu, dalam menyerang musuh, perang laut Indonesia memiliki doktrin untuk tidak menempatkan kapal selam untuk bergerak sendiri. Kapal selam bergerak bersama kapal lain untuk saling melindung (Saragih, 2012) (lihat gambar 1

Gambar 1

Kapal Selam DSME 209/1400

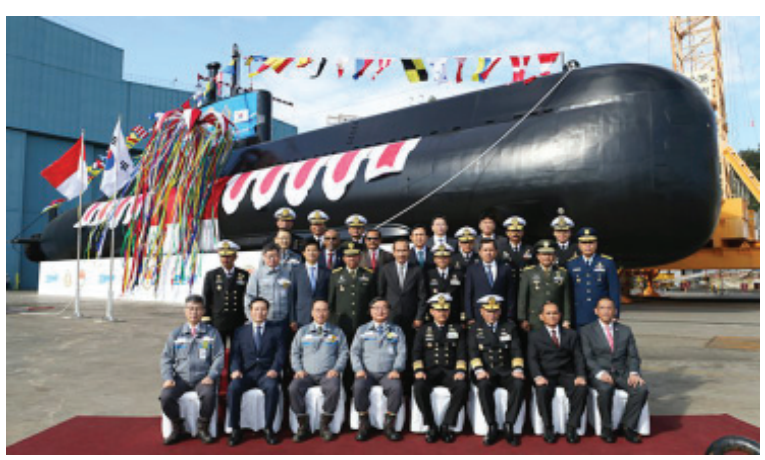

Sumber: Hyo-sik, Lee, 2016.
Tepatnya di tahun 2012, Indonesia dan Korea Selatan mulai merealisasikan pengembangan kapal selam sebagai proyek alutsista yang dinamakan DSME209/1400Submarine (changbogo class). Penambahan kapal selam ini diharapkan dapat menjadi tempat untuk mengolah kemampuan sumber daya manusia (SDM) lokal dalam pembuatan kapal selam. Mantan Wakil Menteri Pertahanan Sjafrie Sjamsoedinmengatakan bahwa dalam kontrak pembelian tiga kapal selam juga sudah meliputi alih teknologi atau transfer of technologypembuatan kapal selam. Berdasarkan kontrak pembelian ketiga kapal selam tersebut, dana diambil dari alokasi pengadaan alutsista tahun 20102014 yangmenghabiskan biaya sekitar USD 1,079.999. Kepala Badan Sarana Pertahanan Mayor Jenderal Ediwan Prabowoberdalih bahwa demi menjamin terlaksananya alih teknologi, pembuatan kapal selam ketiga akan dilakukan sepenuhnya di dalam negeri melaui PT. PAL (Meidiani, 2018) (lihat gambar 2).

Kapal selam kelas changbogo milik Korea Selatan pada awalnya adalah kapal selam Tipe 209/1200 yang telah dimodifikasi sedemikian rupa sejak permulaan abad 21, diantaranyatermasuk penambahan panjang lambung kapal yang disetarakan dengan kapal selam tipe 209/1400 dan tipe209/1500, kemampuan untuk meluncurkan rudal subHarpoon, penggunaan sistem AIP, dan juga sistem akustik penangkal torpedo baru (Torpedo Acoustic Counter Measures/TACM) yang dikembangkan secara mandiri oleh Korea Selatan (Meidiani, 2018).

Untuk memperkuat skuadron kapal selam di Korea Selatan, kapal selam DSME209/1400 sendiri merupakan pesanan khusus dari Korean Navyyang saat ini terdiri 


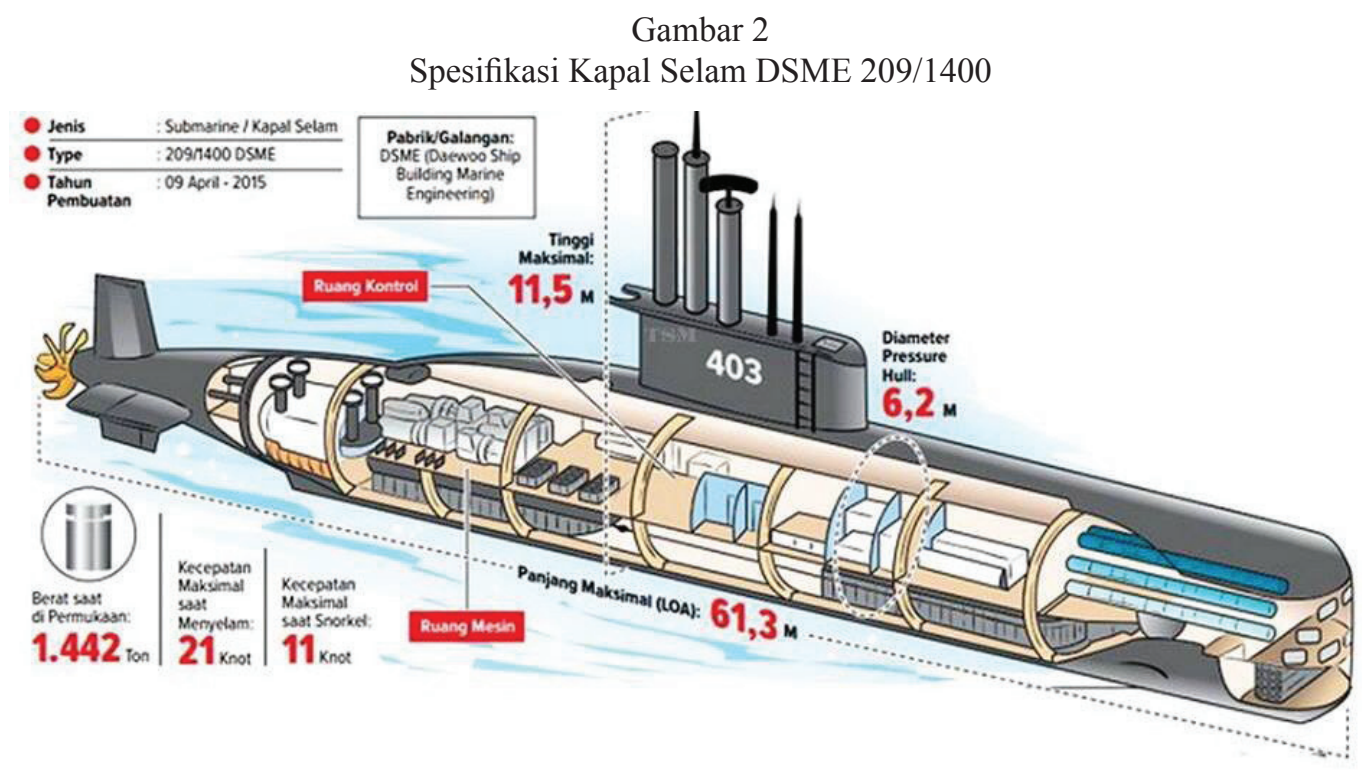

Sumber: Ginanjar, 2017.

dari beberapa kelas yaitu Midget, U209/1200, dan U214/1800. Dimulai sejak awal tahun 2015, proyek desain kapal selam berbobot 3000 ton pembangunannya direncanakan pada tahun 2016 (Jalo, 2015).Meskipunturunan dari tipe U-209 buatan Jerman, spesifikasi yang tinggi juga telah di sematkan secara khusus pada kapal selam DSME209/1400. Spesifikasinya meliputi kesenyapan yang tinggi, mampu menghindari deteksi, mampu menyelam hingga kedalaman 250 meter, pemutakhiran teknologi serta memiliki kecepatan yang mampu melaju hingga 21 knot ketika menyelam. Kapal selam DSME209/1400 juga dituntutuntuk beroperasi terusmenerus selama lebih kurang 50 hari. TNI $\mathrm{AL}$ telah mengirimkan tujuh orang personel yang masing-masing dibekali kemampuan dan pengetahuan khusus mengenai kapal selam jenis 209 secara profesional selama proses pembangunan kapal selam di Korea(Jalo, 2015).

Dalam proses pengembangan satuan tugas kapal tersebut, Komandan Saatgaslah yang bertanggungjawab dengan bantuan personel lainnya. Berikut adalah daftar pembagian tugas secara khusus dalam satuan tugas.

Pertama, pengawas Platform melingkupi bidang permesinan, badan kapal, outfitting, painting, baterai, dan pendorongan serta kelistrikan kapal selam.Kedua, pengawas Sewaco yang mencakup bidang sensor, navigasi, komunikasi, senjata, dan sistem kendali senjata kapal selam.Ketiga,perwira Diklat yang bertugas mengarahkan serta mengendalikan kegiatan pendidikan dan pelatihan untuk awak kapal selam.Keempat, perwira Administrasi dan Logistik yang bertugas mengatur dan mengendalikan proses administrasi kontrak serta sistem logistik komponen-komponen kapal selam. Kelima, kesekretariatan yang bertugas mengendalikan kegiatan ketatausahaan dan administrasi personel dalam satuan tugas kapal selam.

Dari sisi teknologinya, terdapat beberapa keunggulan yang dimiliki oleh kapal selam DSME209/1400. Latest combat system, enhanced operating system, non- 
hull penetrating mast and Comfortable accommodation merupakan State of the art technology yang dimiliki oleh kapal selam ini. Battery buatan Korea Selatan merupakan elemen terpenting dalam kapal selam tipe tersebut untuk sumber tenaga (Jalo, 2015). Jenis baterai kapal selam buatan Korea Selatan ini digunakan pada semua sumber tenaga kapal selam disana. Persenjataan dan sistem kendali senjata di kapal selam ini juga merupakan salah satu nilai unggul. Dipersenjatai dengan 8 buah tabung peluncur torpedo untuk torpedo berukuran $533 \mathrm{~mm}$, kapal selam ini disemati blackshark yang mampumendeploy ranjau laut. Disisi lain,kapal selam ini juga memiliki desain yang mumpuni untuk meluncurkan rudal (Jalo, 2015).

Menyangkut sistem kendali senjata kapal, untuk mengatur dan mengendalikan sistem peperangan dan pekuncuran torpedo, TNI AL memilih sistem kendali senjata MSI MK2 yang dilengkapi dengan sensor dan peralatan elektronika yang canggih dan modern. Jika Flank Array Sonarbelum pernah dimiliki kapal selam Cakra milik Indonesia, maka nantinya sistem ini akan dipasang dan digunakan di kapal selam baru(Jalo, 2015).Dalam kapal selam baru ini, terdapat berbagai keunggulan serta kelebihan sistem dan peralatan yang digunakan jika dibandingkan dengan kapal selam sebelumnya. Di dalam desain kapal selam barunya, TNI AL memilih Radar serta ESM dari IndraSpanyol, Integrated Navigation System dari SAGEM-Prancis, Optronic dan Periskop dari Cassidian-Jerman, dan sistem Sonar dari L3 Elac Nautic-Jerman(Jalo, 2015).

Selain sistem kendali persenjataan, hal terpenting yang menjadi prioritas adalah prosedur keselamatan dan keamanan kapal selam dan personel dalam perancangan desain DSME209/1400. Di kapal selam ini terdapat dua unit life rafts dengan kapasitas 25 personel dengan bekal darurat selama 6 hari. MK-X produksi Inggris sejumlah 48 buah dipilih sebagai pakaian dan keselamatan dan perlindungan dari dekompresi selama proses evakuasi(Jalo, 2015). Sementara itu, bentuk pintu baterai yang dibuat sesuai dengan aturan NAVSEA 0994-LP-013-9010 pada mulut pintunyamerupakan hal yang paling menonjol dibanding dengan kapal selam Cakra. Demikian proses evakuasi menggunakan Deep Submergence Rescue Vehicle (DSRV) dapat di lakukakn (Jalo, 2015).

Adapun skema pembuatan kapal selam terpisah dalam Local Production/ Joint Production yaitu section \#30 dan \#40 di produksi di PT. PAL, sementarasection \#10, \#20 dan \#50 sistem senjata dan sistem pendorong di produksi di DSME, kemudian di PT. PAL Indonesiafinal assembly hinga dengan pembuatan kapal selam dilakssanakan (Prasetyo, dkk, 2017) (lihat gambar 3.

\section{Gambar 3}

Skema Pembagian Pembangunan Kapal Selam DSME 209/1400

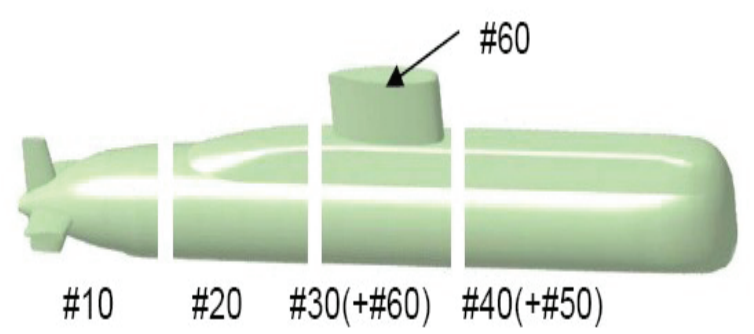

Sumber: Prasetyo, dkk. (2017: 92).

Dalam pengerjaannya, sejumlah 206 orang insinyur dilibatkan oleh PT. PAL Indonesia bekerjasama dengan pihak DSME untuk dididik menjadi ahli dalam pembuatan kapal selam serta terampil di buidang produksi 
kapal. Bayu Wicaksono selaku Manajer Humas PT. PAL Indonesia mengatakan bahwa dari 206 orang insinyuryang terpilih, 120diantaranya ditugaskan untukmerancang kapal selam dan 186 lainnya di bidang produksi, yang mempunyai kualifikasi sebagai desainer sejumlah 20 orang. Secara bertahap sejumlah 120 orang terpilih di bidang perancangan kapal selam dikirimkan untuk meningkatkan kualifikasinya ke Korea Selatan secara bertahap. Dalam hal ini, pembuatan desain merupakan tahap pertama dan kemudian diikuti tahap enginnering, serta tahap berikutnya yaitu perakitan persenjataan. Bayu menerangkan bahwapenandatangananMemorandum of Understanding (MoU) dalam kerjasama tersebut adalah pemerintah Indonesia melalui Kementerian Pertahanan sedangkan pemerintah Korea Selatan diwakili oleh DSME (Jannah, 2018).

Berikut adalah penjelasan pembagian tahapan pengerjaan kapal selam diesel listrik series DSME209/1400 (Prasetyo, dkk, 2017).

Pertama, ahli Korea Selatan dikerjakan sepenuhnya pada kapal selam pertama di galangan kapal Daewoo Shipbuilding and Marine Engineering (DSME) di tahun 2013. Jangka waktu kapal selam pertama dengan nomor lambung H7712 dikerjakan selama 52 bulan (tanggal 9 Maret 2017) dari kontrak efektif tanggal 9 November 2012.

Kedua, tepat pada tanggal 9 Mei 2017, kapal selam kedua dengan nomor lambung H7713 diserahkan setelah 59 bulan, dengan melibatkan ahli dari Korea Selatan dan dikerjakan juga di Korea Selatan sementara pihak Indonesiadiikutsertakandalam proses pelatihan perakitan kapal selam.

Ketiga, dalam kurun waktu 73 bulan, kapal selam ketiga dengan nomor lambung H7714 diserahkan pada tanggal 9 Desember 2018.
Pelatihan menjadi hal utama pada kerjasama pembangunan kapal selam Korea Selatan dan Indonesia ditimbang dari sumber daya manusia di Indonesia yang masih bergantung dengan negara lain dalam pembangunan kapal selam. Sebagai upaya Indonesia untuk mengejar ketertinggalan teknologi, yakni dengan memprioritaskan pelatihan terhadap sumber daya manusia PT. PAL Indoensia (Persero) ataupun stakeholder yang terkait dalam pembangunan kapal.Dibandingkan dengan pembangunan teknologi kapal selam, saat ini sumber daya manusia PT.PAL hanya memiliki kemampuan membangun kapal-kapal atas air. Sepertihalnya isi dari kontrak pada Lampiran F disebutkan bahwa pelatihan telah diatur. Pengadaan pelatihan dan jumlah personel yang dilibatkan dalam pelatihan tersebut diuraikan pada lampiran tersebut (Meidiani, 2018).

Dua dari tiga kapal selam yang diterima pada 09 Mei 2017 lalu, sudah dapat dioperasionalkan oleh pihak pemerintah, sementaradikarenakan belum terpenuhinya beberapa spesifikasi sesuai yang disyaratkan oleh Korea Selatanyang menjadi bentuk ToT masih mengalami hambatan.Dalam hal ini, untuk memberikan keuntungan bagi pihak Indonesia, pihak Korea Selatan memberikan prasyarat sebagai bentuk penjaminan mutu. Sementara itu,dikarenakan pihak Indonesia belum mampu memenuhi prasyarat tersebut, maka hal tersebut justru menjadi penghambat bagi pembangunan kapal selam ketiga (Meidiani, 2018).

\section{Tantangan Yang Ada}

Tantangan Menyiapkan Infrastruktur Pendukung

Menguasai teknologi militer, penguasaan teknologi militer tersebut menggambarkan 
kemampuan industri pertahanan untuk dapat menggerakkan sumber daya yang dimiliki guna membangun dan mengembangkan alutsista merupakan salah satu tujuan kemandirian industri pertahanan.Pada dasarnya, struktur rancang bangun dan teknologi pada kapal selam merupakan teknologi yang mutakhir dan kompleks sehingga untuk mampu menguasai teknologi kapal selam, maka dibutuhkan penerapan strategi dan metode yang sesuai dengan kemampuan dan pengalaman dari sumber daya manusia didukung dengan struktur organisasi, serta penyiapan infrastruktur yang memadai selain juga dukungan dari pihakpihak terkait (Sulistijono, 2017).

Dilihat dari roadmap yang dibuat PT. PAL Indonesia, tercatat PT. PAL Indonesia membagi kegiatan pembangunan dan pengembangan kapal selam DSME 209/1400 menjadi tiga tahapan.

Tahap I program Transfer of Technology dilaksanakan terlebih dahulu melalui proses Joint Section untuk kapal selam ketiga sesuai dengan kontrak awal pembelian tiga kapal selam dari pabrik DSME Korea Selatan.

Tahap II mendahulukan rencana skema Joint Production dengan galangan kapal produsen, dimana PT. PAL Indonesia diharapkan sudah mampu memproduksi pembuatan kapal selam yang dibagi menjadi 5 seksi dari kapal selam yang dibuat keseluruhannya dengan memberdayakan SDM dan fasilitas infrastruktur yang ada di PT. PAL Indonesia (Persero).

Tahap III atau whole production. Dalam hal ini, apabila keseluruhan bagian kapal selam telah mampu diproduksi oleh PT. PAL Indonesia maka proses pembangunan kapal selam dapat dikategorisasikan dalam tahapan ini meskipun masih dalam status Joint Production. Adapun yang dimaksud dengan joint production sendiri adalah desain masih milik galangan kapal produsen sehingga semua peralatan masih berasal dari saran galangan kapal produsen. Meskipun demikian, dalam joint production, semua pelaksanaannya telah diolah oleh SDM sertasaranadan prasarana yang ada diPT. PAL Indonesia. PT. PAL Indonesia memiliki tujuan unutk menguasai teknologi produksinya (Sulistijono, 2017).

Terkait dengan faktor sumber daya manusia, sumber daya manusia sendiri adalah faktor utama dari suksesnya suatu kegiatan perusahaan dalam peningkatan kemampuan penguasaan teknologi khususnya pada proses transfer of technology pembuatan dan pengembangan kapal selam yang dilaksanakan oleh PT. PAL Indonesia dari landasan kapal DSME Korea Selatan. Faktor usia merupakan kesenjangan utama pada sektor Sumber Daya Manusia di PT. PAL Indonesia dimana antar personel yang diganti terpaut selisih usia yang jauh. Selain itu, kesiapan jumlah SDM organik PT. PAL Indonesia sangat tidak memadai, hal tersebut berbanding terbalik dengan tingkat beban pekerjaan yang dihadapi (Sulistijono, 2017).

Adapun usaha yang telah dilakukan PT. PAL Indonesia dalam menyiapkan dan meningkatkan kualitas SDM untuk menghadapi dan melangsungkan proses transfer of technologi perakitan kapal selam dari DMSE Korea Selatan tersebut tampak pada hal-hal sebagai berikut.

Pertama, untuk memenuhi jumlah kebutuhan kebutuhan SDM sesuai dengan yang dibutuhkan dalam melaksanakan transfer of technologydilakukanlah seleksi personel guna memenuhi jumlah. Proses seleksi tersebut dilakukan dengan mengambil personel dari personel struktural PT. PAL Indonesia, sedangkan kekurangannya akan 
diambilkan melalui seleksi personel dari luar PT. PAL Indonesia dengan penilaianefektivitas dan efisiensi. Dalam hal ini, beberapa personel dengan kualifikasi tertentu diambil dari beberapa perusahaan yang sesuai, sebagai contoh personel bidang bending shell pressure hull direkrut personel dari PT. Barata Indonesia, untuk bidang pengkajiankekuatan struktur kapalselam berbasis finite element direkrut personil dari FakultasTeknik Perkapalan (FTK)ITSSurabaya, dan terakhir untuk bidang pengembangan elektronika dan sistem senjata personil diambil dari PENS-ITS Surabaya.

Kedua, selain melakukan seleksi personel, kolaborasiriset juga dilaksanakanoleh PT. PAL Indonesia dengan lembaga pemerintah maupun swasta di antaranya adalahkerjasama dengan LHI-BPPT,Perguruan Tinggi ITS Surabaya, Kementrian Riset dan Teknologi (Dikti), dan Badan Penelitian dan Pengembangan Kementerian Pertahanan.

Ketiga, personel yang akan berangkat mengikuti trainingdibekali dengan materi (1). Pre-trainingperakitan kapal selamolehjasa konsultan dari Korea Selatan; (2). Pembekalan teknis, intelijen dan bela negara oleh TNI AL; (3). Pembekalan keahlian bahasa Inggris dan bahasa Korea; (4). Training dan sertifikasi DT dan NDT untuk pengelasan.

Keempat,mempersiapkan fisikdanmental personel yang akan berangkat dengan mengikuti training OJT/ToT, yaitu (1). Training Korean culture lecture and leadership; (2).Pengarahan dari Direksi PT. PAL Indonesia; (3). Penyuluhan dari Project Officer Kementerian Pertahanan

Kelima, untuk mengikuti pelatihan program transfer of technology pembuatan kapal selam di galangan kapal DSME Korea Selatan dikirimkan personel yang telah terealisasi sejumlah 206 personel.
Keenam, menangani materi yang telah diperoleh dari DSME dengan cara: (1). Sembari menunggu pelaksanaan kegiatan joint section untuk kapal selam ketiga di PT. PAL Indonesia, personil yang telah menempuh OJT di DSME dan telah kembali ke PT.PAL Indonesia ditugaskan untuk membuat laporan lengkap tentang semua kegiatan yang diikuti, seluruh data dikumpulkan di satu tempat dan diberi password. (2). Untuk mempertahankan dan mengaplikasikan ilmudan kemampuan di bidang masing-masing yang telah diperoleh dari pelatihan ToT maupunOJT, personil tersebut akan dilibatkan untuk mendukung kegiatan overhaul KRICakra-401 dan kegiatan overhaul KRINanggala-402.

Ketujuh, mengadakan koordinasi dan tindak lanjut kolaborasi dengan membentuk suatu team sebagai fasilitas kerja bersama secara lebih detaildengan tujuan menemukan jalan keluar bagi persoalan yang bisa munculdalam rentang proses terjadinya transfer teknologi, yang beranggotakan tim ahli dari PT. PAL Indonesia serta tim ahlidariDSME. Mereka memiliki tugas utama mendiskusikan dan menyusun secara rinci prosalan yang muncul selama proses transfer of technology dilakukan.

Kedelapan, mengoptimalkan jasa konsultan untuk membantu membuat perencanaan pengembangan infrastruktur maupun dalam penyediaankemampuanSDM. Sebagai contoh, berapa kuantitas personel yang patut disiapkan sesuai bagian yang dibutuhkan, teknologi yang harus dicapai dan kuasai, maksudnya hingga level apa teknologi dapat dikuasai agar bisa mampu dan mandiri (Sulistijono, 2017).

Untuk menyelesaikan galangan kapal selam dengan desain bangunan maupun layout penempatan peralatan dan perlengkapan joint 
section,PT. PAL Indonesiatelah membangun fasilitas infrastruktur sarana dan prasarana serta peralatan dan perlengkapan. Dalam hal ini, semuanya disamakan dengan konsep dari galangan kapal DSME Korea Selatan sebagai landasan kapal penyumbang transfer teknologi. Beberapa hal yang harus diperhatikan dan diantisipasi oleh PT. PAL Indonesia dalam persiapan dan pembangunan fasilitas infrastruktur, peralatan, dan perlengkapan untuk galangan kapal selam, hal yang dimaksud adalah munculnya prediksi mengenai fleksibilitas dari fasilitas infrastruktur dan peralatan maupun perlengkapan yang masih dibangun untuk dirancang dengan sedemikian rupa agar fungsi dan produktifitasnya masih bisa relevanuntukbeberapa puluh tahun kedepan dengan mempertimbangkandan memperhitungkan adanya kemungkinan dilaksanakannya penambahan, peningkatan kemampuan, danmodifikasi (Sulistijono, 2017).

PT. PAL Indonesia sendiri telah membangun fasilitas infrastruktur dan menyiapkan peralatan maupun melengkapi perlengkapan untuk sarana dan prasarana galangan kapal selamsupaya mampu melaksanakan keseluruhan whole production. Namun demikian, dalam proses perjalanannya sempat terjadi perubahan kebijakan pemerintah yang mengakibatkan pembangunan fasilitas tidak berjalan sesuai dengan ekspetasi. Limitasi dukungan pemerintah Indonesia hanya mampu untuk memenuhi kepentingan fasiltas dan peralatan atau perlengkapan untuk melaksanakan joint section(Sulistijono, 2017).

Kondisi ideal kerjasama industri pertahanan Indonesia dengan Korea Selatan sebenarnya telah memenuhi tujuan Indonesia yaitu membangun pertahanan secara mandiri, namun demikian dalam pelaksanaan kerjasama tersebut faktanya terdapat berbagai hambatan. Menurut Timbul Siahaan, selepas kerjasama Indonesia-Korea Selatan timbul beberapa hambatan yang menyebabkan pembangunan kapal selam secara mandiri masih belum dapat dilaksanakan. Materialkapal selam yang belum dapat disuplai dari dalam negeri juga menimbulkan hambatan. Contohnya adalah plat baja yang digunakan sebagai bangunan kapal selam. Dalam hal ini, Korea sendiri masih bergantung pada sektor impor plat baja dari Jerman. Roll terhadap baja bisa saja dilakukan oleh PT. Krakatau Steel, namun material berupa plat baja masih harus diimpor" (Prasetyo, dkk, 2017: 99).

Terkait hal ini, LaksdaTNI (Purn) Rachmad Lubis berpendapat bahwa hambatan yang dimaksud adalah PT. Krakatau Steel belum mampu memproduksi bahan kapal selam berupa baja; kurangnya pendanaan;SDM dan teknologi yang belum memadai; dan payung hukum yang belum sepenuhnya didukung oleh pemerintah (Prasetyo, dkk, 2017). Ia berpendapat bahwa dalam proses kerjasama pembangunan dan pengembangan kapal selam DSME 209/1400, TOT tidak mampu berjalan dengan lancar dikarenakan pengkhususan SDM yang ditetapkan oleh Korea Selatan belum mampu dipenuhisehingga pengiriman personil mengalami hambatan.

Hasil analisis data di atas membuktikan evaluasi dalam pemenuhan tujuan keberlanjutan pembangunan kemandirian alutsista belum dapat dipenuhi.Selepas dari kerjasama Indonesia-Korea Selatan, keberlanjutan pembangunan alutsista akan merujuk pada pemahaman pengembangan keahlian industri pertahanan membangun kapal selam. Hal ini setidaknya disebabkan olehbeberapa hambatan seperti PT. Krakatau Steel belum mampu memproduksi bahan kapal 
selam berupa baja; kurangnya pendanaan; sertaSDM dan teknologi yang belum memadai (Prasetyo, dkk, 2017).

\section{Tantangan Kebijakan Kerjasama}

Pelaksanakan penelitian dan pengembangan rekayasa teknologi akan selalu sebanding pada dukungan finansial dari pemerintah.Konsep pola besar yang dipakai oleh KKIP dalam menperluas kemandirian industri pertahanan setidaknya diukur dari tiga kapasitas, salah satunya adalah kapasitas finansial atau kapasitas ekonomi nasional, maka keberhasilan industri pertahanan dalam mendapatkan keberhasilannya mencapai kemandiriansalah satunya ditentukan oleh kemampuan dukungan dana (Prasetyo, dkk, 2017). Dalam hal ini, dapat diintepresetasikan bahwa kualitas kekuatan militer dapat terbangun sesuai dengan kemempuan ekonomi.

Selain persoalan finansial, kebijakan pemerintah menjadi penentu atas kelangsungan pengembangan teknologi industri pertahanan untuk menuju kemandirian. Upaya kemandirian PT. PAL Indonesia sebagai industri strategis pertahanan nasional di bidang maritim juga harus diperhatikan oleh pemerintah sebagai pembuat kebijakanbaik dari sisi peraturan maupun perundang-undangan yang dapat digunakan sebagai payung hukummaupun dari sisi keputusandan penentuan rencanapembelian alutsista kedepan untuk dapat menguasai dan mengembangkan satu jenis yang sama dulu. Disini dibutuhkan konsistensi kebijakan dari pemerintah (Sulistijono, 2017).

Untuk mencapai kemandirian dalam memproduksi alutsista,sejauh ini pemerintah telah menetapkan Undang-Undang Republik Indonesia No. 16 Tahun 2012 tentang Industri Pertahanan sebagai undang-undang yang mendukung upaya industri pertahanan dalam negeri. Sesuai dengan Pasal 3 UU RI No. 16 Tahun 2012 yang berbunyi: (1). Mewujudkan industri pertahanan yang profesional, efektif, efisien, terintegrasi, dan inovatif. (2). Mewujudkan kemandirian pemenuhan alat peralatan pertahanandan keamanan, dan yang terakhir. (3). Meningkatkan kemampuan memproduksi alat peralatan pertahanan dan keamanan, jasa pemeliharaan yang akan digunakan dalam rangka membangun kekuatan pertahanan dan keamanan yang andal(Undang-Undang Republik Indonesia Nomor 16 Tahun 2012).

Penetapan undang-undang tersebut didasari oleh adanya visi yang harus diterapkan untuk mencapai kesuksesan dan kemandirian industri pertahanan dalam negeri.Visi tersebut memuat semangat untuk mewujudkan kemampuan produksi secara mandiri alat peralatan pertahanan dan keamanan. Kemampuan industri pertahanan harus didukung oleh manajemen yang cakap serta mengandalkan sumber daya manusia yang mempunyai standar kapasitas dan kapabilitas tinggi. Hal ini dapat mendorong tercapainya kebutuhan teknologi alat peralatan pertahanan yang kebutuhannya selalu menyesuaikan perkembangan zaman (Undang-Undang Republik Indonesia Nomor 16 Tahun 2012).

PT. PAL Indonesia hadir sebagai jawaban atas salah satu tuntutan dan tantangan Negara Kesatuan Reoublik Indonesia yang memiliki indusri strategis pertahanan dan keamanan. Namun demikian, sangat di sayangkan bahwa kemampuan PT. PAL Indonesia masih tergolong terbatas sehingga diperlukan usaha untuk melakukan peningkatan dan pemanfaatan industri pertahanan. Independensi pertahanan dan keamanan membutuhkan semangat dan koordinasi yang baik dari semua kalangan, serta harus didukung oleh kebijakan 
Pemerintah dalam pemberdayaan segenap kemampuan sumber daya nasionaltermasuk perangkat regulasi (Undang-Undang Republik Indonesia Nomor 16 Tahun 2012).

Dengan adanya perangkat pengaturan yang jelas dan tegasserta wujud pembangunan sistem industri pertahanan yang teroganisir, efektif, dan efisien, maka pemberdayaan segenap kemampuan industri nasional untuk mendukung pemenuhan kebutuhan alat peralatan pertahanan dan keamanan dapat dimaksimalkan. Adanya dasar hukum tentang pelaksanaan sektor industriketananan nasional, seperti aturan dalam undang-undang mengenai industri pertahanan sejatinya dapat memperkuat serta mengoptimalkan industri supaya dapat mencapai independensi pemenuhan kebutuhan alat peralatan pertahanan dan keamanan (Undang-Undang Republik Indonesia Nomor 16 Tahun 2012).

Tujuan, fungsi, dan ruang lingkup dari industri pertahanan diatur dalam UndangUndang RI No. 16 Tahun 2012. Disamping itu, hal-hal yang diaturjuga bersangkutan dengan kelembagaan, Komite Kebijakan Industri Pertahanan (KKIP), tata industri pertahanan, dan hasil produk dari seluruh proses produksi yang dilakukan industri pertahanan yang dipasarkan.

\section{SIMPULAN}

Berdasar uraian di atas dapat ditarik simpulan sebagai berikut.

Pertama, kerjasama antara Indonesia dengan Korea Selatan dalam pengembangan kapal selam sebagai proyek alutsistaDSME-209/1400 Submarine (Changbogo Class) merupakan kebijakan untuk memperkuat visi pengadaan kapal selam Indonesia pada tahun 2024, serta meningkatkan kemampuan sumber daya manusia (SDM) terkait pembuatan kapal selam. Dengan demikian, kerjasama ini lebih dari sekedar pembelian alutsista semata, ia merupakan bagian dari kebijakan strategis Indonesia dalam mewujudkan kemandirian maritim di masa yang akan datang.

Kedua, kerjasama antara Indonesia dengan Korea Selatan mengedepankan skema alih teknologi untuk mendukung kemandirian dan kemajuan industri serupa di dalam negeri yang dipimpin pengembangannya oleh PT. PAL Indonesia. Namun demikian, penelitian ini menemukan adanya kendala dan tantangan yang dihadapi dalam peningkatan kapal selam tersebut, khususnya terkait dengan kemampuan PT. PAL Indonesia yang masih terbatas dalam pembuatan kapal selam DSME 209/1400. Keterbatasan tersebut dikarenakan: (1).Indonesia belum memiliki kemampuan dalam bidang rancang bangun kapal selam, serta masih kurang optimalnya fasilitas infrastruktur saranadan prasarana yang dimiliki oleh PT PAL Indonesiasendiri dalam kegiatan pemeliharaan, perbaikan, maupun pembuatan kapal selam; (2). Kemampuan sumber daya manusia yang dimiliki oleh PT. PAL Indonesia masih terbatas dan minim pengalaman dalam merancang kapal selam, begitu juga dalam kelemahan dalam menguasai teknologi terbaru.

Selanjutnya direkomendasikan hal sebagai berikut.

Pertama, Kementerian BUMN yang membawahi BUM, sebagai bahan pelaksanaan dan pengadaan infastruktur yang akan melaksanakan proses transfer of technology, hendaknya menginventarisir perusahanperusahaan nasional yang bergerak pada sektor industri pertahanan. Hal ini dimaksudkan untuk mengantisipasi terhambatnya proses revitalisasi industri pertahanan yang belum 
Faris Al-Fadhat, Naufal Nur Aziz Effendi -- Kerjasama Pertahanan Indonesia-Korea Selatan: Ketahanan Maritim dan Transfer Teknologi dalam Pengadaan Kapal Selam DSME 209/1400

siap untuk melaksanakan transfer of technologyseperti yang tercermin dari PT. PAL Indonesia.

\section{DAFTAR PUSTAKA}

Agussalim, D. \& Alfadh, M. F. 2011. "Kekayaan dan Supremasi Politik: Menguatnya Ancaman Konflik Terbuka dalam Gelimang Globalisasi”. Verity: Jurnal Hubungan Internasional,3:5, 1-19.

Badan Sarana Kementrian Pertahanan Republik Indonesia.2010. "Kebijakan Pertahanan Negara Tentang Minimum Essential Force Komponen Utama", diakses dari https://www.kemhan.go.id/ baranahan/2010/03/02/kebijakanpertahanan-negara-tentang-minimumessential-force-komponen-utama.html, pada 01 Januari 2019.

Dewan Perwakilan Rakyat Republik Indonesia. 2012. Laporan Kunjungan Kerja Komis I DPR-RI Seoul, Busan Republik Korea Selatan 26 Desember-30 Desember 2011. Ginanjar, D. 2017. “Selamat Datang, Nagapasa! Kapal Selam Baru Milik Indonesia", Jawa Pos, diakses darihttps://www.jawapos. com/nasional/hankam/28/08/2017/ selamat-datang-nagapasa-kapal-selambaru-milik-indonesia/, pada 14Oktober 2019.

Hyo-sik, L. 2016. "DSME launches 2nd submarine for Indonesia", The Korea Times, diakses darihttp:// www.koreatimes.co.kr/www/news/ biz/2016/10/123_216676.html, pada 8 Oktober 2019.

Inspektorat Jenderal Kementrian Pertahanan Republik Indonesia. 2014.”Peraturan Menteri Pertahanan Republik Indonesia Nomor 26 Tahun 2012 Tentang Rencana
Strategis Pertahanan Negara Tahun 2010-2014", diakses dari https:// www.kemhan.go.id/itjen/2012/08/14/ peraturan-menteri-pertahanan-republikindonesia-nomor-26-tahun-2012tentang-rencana-strategis-pertahanannegara-tahun-20102014.html, pada 28 Desember 2018.

Jalo. 2015. "Changbogo, Siluman Penjaga Nusantara", diakses darihttps:// jakartagreater.com/changbogo-silumanpenjaga-nusantara/, pada 28 Oktober 2018.

Jannah,S.M., 2018, "RI-Korea Kerjasama Bikin Kapal Selam, Ini Progesnya", diakses dari https://finanmce.detik.com/ industri/d-4293714/RI-Korea-kerjasama-bikin-kapal-selam-ini-progresnya, pada 12 November 2019

Julaikah, N. 2014. "Ini alasan pemerintah beli kapal selam dari Korea Selatan", diakses dari https://www.merdeka.com/ uang/ini-alasan-pemerintah-beli-kapalselam-dari-korea-selatan.html, pada 25 Oktober 2018.

KBRI Seoul. (tanpa tahun). "Indonesia dan Korea Selatan selenggarakan joint commission meeting ke-2 untuk lebih perkokoh kerjasama bilateral", diakses dari http://www.kbriseoul.kr/ kbriseoul/index.php/id/2013-01-21-2249-05/berita-terkini/544-indonesiakorea-selatan-selenggarakan-jointcommission-meeting-ke-2-untuk-lebihperkokoh-kerjasama-bilateral, pada28 Oktober 2018.

Meidiani, S. A. 2018. Kerjasama Indonesia - Korea Selatan dalam Industri Kapal Selam Indonesia Tahun 2011-2016". Jurnal Ilmu Hubungan Internasional,6:3, 1220. 
Ministry of Foreign Affairs of The Republic of Indonesia. (2014). Letter of Intent on Co-development of a Fighter Jet Project between the Department of Defense of the Republic of Indonesia and the Defense Acquisition Program Administration of the Republic of Korea.

Pramodhawardani, J. 2009. "Efisiensi Manajemen Alutsista", diakses dari http://lipi.go.id/berita/efisiensimanajemen-alutsista/4389, pada 2 Januari 2019.

Prasetyo, T., Armawi, A., \& Salim, D. A. 2017. "Evaluasi Kinerja KKIP Dalam Kerjasama Republik Indonesia-Korea Selatan Pada Pembangunan Kapal Selam Untuk Mendukung Ketahanan Alutsista TNI Angkatan Laut”. Jurnal Ketahanan Nasional, 23:1, 86-103.

Puspen TNI. 2005. "PembinaanMental Merupakan Fungsi Komando", diakses dari https://tni.mil.id/view-1416pembinaan-mental-merupakan-fungsikomando.html, pada 8 Januari 2019.

Puspen TNI. 2007. "Validasi Organisasi Dan Revisi Doktrin TNI Telah Selesai”, diakses dari https://tni.mil.id/view-4526-validasiorganisasi-dan-revisi-doktrin-tni-telahselesai.html, pada 9 Januari 2019.

Rizanny, D. 2017. "Mengapa Indonesia perlu Kapal Selam Konvensional Jarak Jauh?", diakses dari, http://maritimnews. com/2017/06/mengapa-indonesia-perlukapal-selam-konvensional-jarak-jauh/, pada 5 Juni 2019.

Romansyah, B.S. 2015. "Kerjasama Jerman dan Indonesia dalam Hal Pembelian Senjata Milliter untuk Modernisasi Alutsista TNI". Jom FISIP, 2:1, 1.

Rusman. 2018. "Pentingnya Minimum Essential Force (MEF) sebagai Strategi
Kebijakan Pertahanan Indonesia", diakses dari http://theglobal-review. com/pentingnya-minimum-essentialforce-mef-sebagai-strategi-kebijakanpertahanan-indonesia/, pada 5 Januari 2019.

Saragih, R. 2013. "Minimum Essential Force TNI Tahap 2 (2015-2019)", diakses dari http://jakartagreater. com/minimum-essential-force-tnitahap-2-2015-2019/>, pada 3 Januari 2019.

Schreer, Benjamin, 2013. Moving beyond ambitions? Indonesia's military modernization. Barton, Australia: ASPI.

Seung-Yoon, Y.2005. 40 Tahun (1966-2005) Hubungan Indonesia Korea Selatan. Yogyakarta: Gadjah Mada University Press.

Sisriadi. 2016. "Pengembangan Postur Perthanan Milliter Guna Mendukung Terwujudnya Poros Maritim Dunia”. Media Informasi Kementrian Pertahanan,59:43, 7.

Sulistijono, R. K. 2017. “Kemandirian PT.PAL Indonesia (Persero) sebagai Industri Strategis Pertahanan Nasional dalam Pembuatan Kapal Selam Diesel Electrik Klas 209”. Jurnal Strategi Perang Semesta,3:1, 25-39.

Supriatin. 2018. “Tahun Depan, Pemerintah Tambah Anggaran Alutsista Menjadi Rp 75 Trilliun", diakses dari https://www. merdeka.com/peristiwa/tahun-depanpemerintah-tambah-anggaran-alutsistamenjadi-rp-75-trilliun.html, pada 16 Januari 2019.

\section{Peraturan Perundangan}

Undang-Undang No. 16 Tahun 2012 Tentang Industri Pertahanan 